\title{
Proses Perubahan Perilaku Berhenti Merokok: Studi Kualitatif Mengenai Motif, Dukungan Sosial dan Mekanisme Coping
}

\section{The Process of Smoking Cessation Behavior Change: A Qualitative Study of Mo- tives, Social Support and Coping Mechanisms}

\author{
La Ode Reskiaddin ${ }^{1}$, Supriyati $^{2}$
}

${ }^{1}$ Program Studi Kesehatan Masyarakat, Fakultas Kedokteran dan Ilmu Kesehatan Universitas Jambi, Jambi 36361

${ }^{2}$ Departemen Perilaku, Kesehatan Lingkungan dan Kedokteran Sosial, Fakultas Kedokteran, Keperawatan dan Kesehatan Masyarakat, Universitas Gadjah Mada, Yogyakarta 55281

*Korespondensi penulis:

ld.reskiaddin@unja.ac.id
Diterima (Recieved)

Direvisi (Revised)

Diterima untuk diterbitkan (Accepted)
: 19 Agustus 2020

: 3 Juni 2021

: 25 Juni 2021

\section{ABSTRAK}

Latar Belakang. Tingginya jumlah perokok sebenarnya juga diiringi dengan tingginya keinginan untuk berhenti merokok, namun tidak semua berhasil berhenti merokok.

Tujuan. untuk menggali peran motivasi, dukungan sosial, mekanisme coping dalam upaya berhenti merokok.

Metode. Penelitian kualitatif dengan rancangan penelitian fenomonologi. Teknik snowball sampling dan rekrutmen via whatsapp digunakan untuk mendapatkan informan, dan dipilih menggunakan purposive sampling. Data dikumpulkan melalui wawancara mendalam kapada 18 orang yang terdiri dari 5 orang (1 perempuan 4 laki-laki) yang sudah berhenti merokok 6 bulan sampai 2 tahun, 4 orang yang sedang berhenti merokok ( $<6$ bulan) dan 9 orang sebagai significant others. Keabsahan data melalui triangulasi, member checking dan peer debrieving.

Hasil. Faktor sosial merupakan penyebab yang mendominasi untuk merokok. Motif kesehatan adalah motif utama untuk berhenti merokok. Dukungan untuk berhenti merokok diantaranya dukungan secara emosional dan instrumental.

Kesimpulan. Perokok berhenti merokok karena motif kesehatan seperti ingin lebih sehat. Motif non kesehatan diantaranya haram dan pengeluaran membeli rokok lebih banyak dari kebutuhan untuk makan. Coping kognitif seperti mensugesti diri melalui perubahan mindset sebagai salah satu strategi yang dapat dilakukan untuk mengendalikan perilaku merokok. Dukungan sosial hanya sebagai penguat atau moderator. Coping merupakan pengendali utama dalam berhenti merokok. Dukungan sosial sebagai moderator dalam proses berhenti merokok.

Kata Kunci: Berhenti merokok, dukungan sosial, mekanisme coping, usia produktif

\section{ABSTRACT}

Introduction. A high number of smokers aligned with smoking cessation eagerness, but not all succeed.

Objective. to explore the motive, social support and coping mechanism for smoking cessation

Methods. Qualitative research with phenomenology research design. We did the snowball sampling technique and participants' recruitment via WhatsApp and Purposive sampling. 18 in-depth interviews consisted of 5 participants ( 1 woman and 4 men) who quit smoking within the past 6 months to 2 years, 4 participants who are quitting smoking ( $<6$ months) and 9 people as significant others. Data validation was through triangulation, member checking and peer debriefing.

Results. Social factors are the dominant cause of smoking. Health motives are the main motives for quitting smoking. Support for quitting smoking includes emotional and instrumental support

Conclusion. Smokers' motivations to quit due to health reasons such as a better level of health. Non-health reasons are religious prohibition (haram) and cigarette expenses higher than primary (food) expenditure. Research also found cognitive coping such as personal suggestion through mindset change, is one of the strategies to control smoking behavior. Social support as a booster or moderator. Coping is the primary controller in smoking cessation. It's strengthened by personal willingness. Social support acted a moderator.

Keywords: Smoking cessation, social support, coping mechanism, adolescent 


\section{LATAR BELAKANG}

Kematian akibat tembakau melebihi kematian yang terjadi pada perang dunia I dan II yaitu sebanyak 100 juta orang dan meningkat menjadi 1 milyar pada abad ke-21. ${ }^{1}$ Proporsi perokok di Indonesia dari tahun 2007 ke tahun 2013 mengalami peningkatan dari 23,7\% hingga mencapai $24,3 \%$. Apabila tidak dilakukan upaya untuk mengontrol hal tersebut maka jumlah perokok diprediksikan akan terus meningkat. ${ }^{2}$ Berdasarkan hasil survei Perilaku Hidup Bersih dan Sehat (PHBS) di $\mathrm{DIY}^{3}$, perokok yang merokok di dalam rumah sebesar 50,21\% (2014), 48,66\% (2015) dan 46,15\% pada tahun 2016 .

Tingginya jumlah perokok juga diiringi dengan tingginya keinginan untuk berencana dan berpikir berhenti merokok yaitu 50-70\%. Sayangnya hanya $3 \%$ perokok yang berhasil berhenti merokok. ${ }^{4,5}$ Berdasarkan data jumlah kunjungan pasien layanan berhenti merokok di RS Respira pada tahun 2010 ada 382 pasien konseling berhenti merokok diantaranya 21 orang berhasil berhenti merokok dan 361 orang belum berhenti merokok. ${ }^{6}$ Penelitian Huges menyebutkan sebanyak 40\% perokok di Amerika dan Inggris memiliki keinginan untuk berhenti merokok namun 95\% diantaranya gagal berhenti merokok. ${ }^{7}$

Berhenti merokok bukanlah hal yang mudah dan singkat dilakukan. Butuh waktu yang lama agar benar-benar dikatakan telah berhenti merokok. Menurut Teori Transteotrical Model oleh Prochaska \& DiClemente ${ }^{8}$ tahapan perubahan perilaku berhenti merokok hingga berhenti merokok meliputi prekontamplasi, kontamplasi, aksi, maintenance dan terminasi. ${ }^{9}$ Seseorang yang berhenti merokok apabila telah menghentikan kebiasaan merokoknya minimal 1 tahun. ${ }^{10}$ Ada beberapa motif yang mendasari seseorang berhenti merokok diantaranya adanya sebuah tekanan sakit fisik dengan risiko kematian, norma sosial, evaluasi dari biaya dan manfaat dari berhenti merokok, dan berhenti merokok menjadi tanggung jawab pribadi mereka. ${ }^{4,11,12}$

Mekanisme coping merupakan strategi yang digunakan untuk mengatasi tekanan, rasa sakit, dan perubahan alami yang dirasakan. Banyak orang menggunakan mekanisme coping untuk memberi manfaat bagi mereka secara positif. Dukungan sosial merupakan salah satu kunci keberhasilan dalam upaya berhenti merokok. Individu yang kurang memperoleh dukungan sosial dapat meningkatkan kerentanan, sedangkan individu yang mempunyai dukungan dapat mengurangi konsekuensi dari paparan situasi dan faktorfaktor yang memiliki dampak buruk terhadap perilaku kesehatan. ${ }^{13}$ Oleh karena itu, penelitian ini bertujuan untuk menggali pengalaman perokok dalam berhenti merokok ditinjau dari motivasi, dukungan sosial dan mekanisme coping.

\section{METODE}

Penelitian ini menggunakan penelitian kualitatif dengan rancangan penelitian fenomenologi. Penelitian dilakukan di Daerah Istimewa Yogyakarta, dengan subjek penelitian perokok yang telah dan belum berhasil berhenti merokok. Informan diperoleh melalui media sosial (whatsapp), snow ball dan penelusuran register klinik berhenti merokok. Cara pengambilan sampel menggunakan teknik purposive sampling melalui pendekatan criteration sampling yang meliputi a) Pria dan wanita yang telah berhenti merokok bukan karena sakit, b) Usia produktif 15-64 tahun, c) Pertama kali berhasil berhenti merokok, d) Perokok yang telah berhenti lebih dari 6 bulan sampai 2 tahun. Data dikumpulkan melalui wawancara mendalam kepada 18 orang informan yang terdiri atas 5 orang yang telah berhenti merokok, 4 orang yang sedang berusaha atau belum berhasil berhenti baik dan 9 orang sebagai significant others. Data dianalisis menggunakan open code 4.03 . Keabsahan data melalui triangulasi data, member checking dan peer debriefing.

\section{HASIL}

\section{Karakteristik Informan}

Informan dalam penelitian ini adalah masyarakat yang berdomisili di Yogyakarta meliputi orang yang telah berhenti merokok, sedang berhenti merokok atau gagal berhenti merokok. Jumlah informan dalam penelitian ini sebanyak 18 informan meliputi informan utama sebanyak 5 orang yang telah berhenti merokok, 4 orang yang sedang mencoba atau belum berhasil merokok sebagai pembanding dan 9 orang sebagai informan triangulasi. In- 
forman utama dalam penelitian ini terdiri atas 1 orang perempuan dan 4 orang laki-laki dengan rata-rata umur 26 tahun dan rentang usia berkisar 20-34 tahun. Informan pendukung sebanyak 1 orang perempuan dan 3 orang laki-laki dengan rentang umur 25-30 tahun.

Usia informan merokok pertama kali dan merokok secara regular baik informan utama (yang telah berhenti merokok) dan pembanding (belum berhasil berhenti merokok) didominasi pada usia 13-20 tahun. Informan memulai menjadi perokok ketika semasa SMA dan kuliah. Para informan utama ketika menjadi perokok, jumlah rokok yang dihabiskan dalam sehari yaitu sebanyak 1-10 batang, sedangkan informan pembanding paling banyak 11-20 batang perhari atau sekitar 2 bungkus rokok. Lama berhenti merokok bervariasi dan yang paling lama 2 tahun dan terendah 1 tahun untuk informan utama, sedangkan informan pembanding mencoba berhenti merokok paling lama sekitar 1 sampai 3 bulan atau kurang dari 6 bulan.

\section{Proses Perubahan dan Bukti Perilaku Merokok Menjadi Perilaku Tidak Mero- kok Pada Mantan Perokok}

Penelitian menganalisis tahapan, proses dan bukti perilaku merokok menjadi tidak merokok pada mantan perokok meliputi alasan merokok, alasan berhenti merokok, hambatan berhenti merokok, dukungan sosial dan mekanisme coping dalam berhenti merokok (Bagan 1).

\section{a. Alasan merokok}

Faktor sosial merupakan penyebab yang mendominasi informan untuk merokok. Salah satu bentuk faktor sosial adalah pergaulan atau interaksi antara informan dan teman sebaya. Saat masa remaja, tingkat rasa penasaran untuk mencoba sesuatu cenderung tinggi. Selain tawaran merokok, berbagai perkataan negatif dari teman sebaya memicu rasa ingin mencoba merokok semakin besar. Berbagai perkataan tersebut memicu remaja lebih tertantang untuk mencoba merokok, sehingga informan akan menunjukkan identitas sosialnya di depan teman-temannya. Namun, apabila tidak dicoba maka informan akan merasa lemah dihadapan teman-temannya. Ketika informan menjadi seorang perokok dalam jangka waktu yang lama (persisten), maka semakin banyak alasan atau motif yang memicu untuk terus merokok. Faktor sosial masih menjadi pengaruh terbesar untuk terus merokok. Lingkungan sosial informan sebagian besar adalah perokok sehingga informan akan lebih mudah mendapatkan rokok dari temannya. Selain itu, kebebasan yang diberikan orang tua membuat informan merasa bebas untuk merokok. Faktor lainnya adalah aspek psikologis seperti stres, beban pekerjaan, dan adanya permasalahan yang dialami informan. Faktor finansial juga memberikan pengaruh terhadap informan untuk merokok. Informan merokok karena mampu membeli rokok menggunakan uang mereka sendiri.

\section{b. Alasan Berhenti Merokok}

Motif kesehatan merupakan motif utama informan untuk berhenti merokok. Motif tersebut sangat erat kaitannya dengan kualitas hidup yang mereka inginkan, bukan motif karena sakit. Adapun motif kesehatan tersebut terdiri dari faktor pengalaman, kualitas hidup yang lebih baik, lingkungan dan psikososial. Faktor pengalaman yang dimaksudkan ialah informan berhenti merokok karena pengalaman masa lalu yang buruk pada masa anakanak. Pengalaman tersebut dijadikan dasar untuk mengambil keputusan berhenti merokok.

“...saya gak ngerokok ngerokok lagi karena
saya ngelihat pengalaman saya mama saya
ngerokok pas hamilin saya, sayanya sakit
sakit gitu, saya udah gak mau anak saya sa-
kit begitu, cukup saya saja” (DS, 21 tahun,
Pr)

Selain karena faktor pengalaman yang tidak mengenakan yang pernah dialami seperti penyakit radang paru-paru yang dialami. Motif lainnya adalah karena ingin hidup lebih sehat (kualitas hidup) dan faktor lingkungan. Hal tersebut disebabkan informan telah menyadari bahaya rokok yang akan terjadi pada dirinya apabila terus merokok, walaupun pengetahuan mereka mengenai bahaya rokok sudah ada.

\footnotetext{
"Emmmm... itu... pertama... saya pingin.... kembali sehat gitu... itu... pengen hidup lebih sehat gitu (...) saya tidak mengganggu tidak memberi dampak negatif buat kehidupan orang lain dan juga lingkungan gitu..." (Haf, 34 tahun, Lk)
} 
Bagan 1. Tahapan, Proses Perubahan dan Bukti Perilaku Merokok menjadi Perilaku Tidak Merokok Pada Mantan Perokok

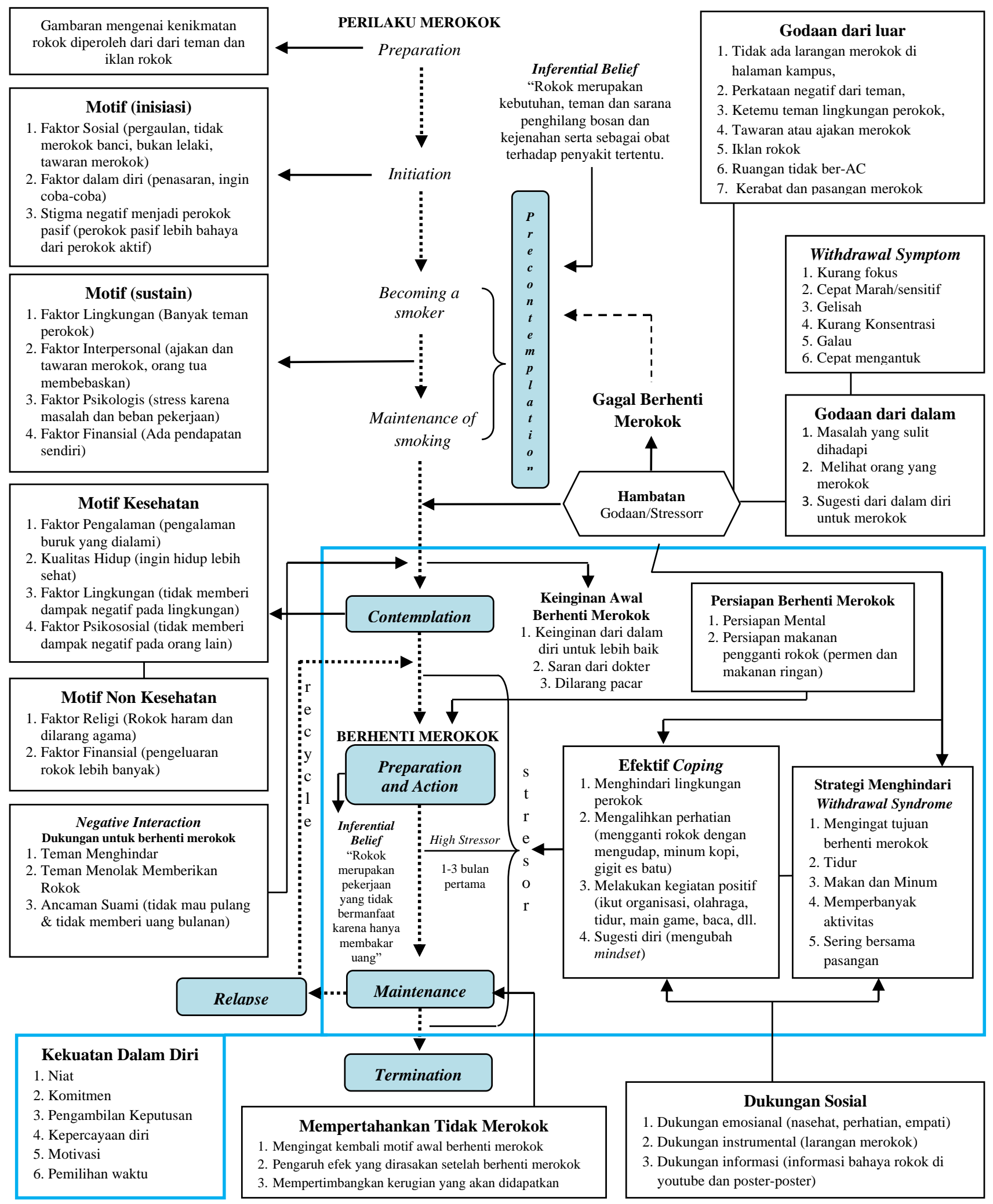

Keterangan:

- : Mempengaruhi
$-\_-\_\cdot$ : Penunjuk Alur
- : Mempengaruhi (internal)


Informan juga memutuskan berhenti merokok karena ada beberapa pengaruh dari pasangannya yang tidak suka dengan perokok karena bau rokok yang ditimbulkan. Oleh karena itu, informan memilih untuk berhenti untuk menjaga kenyamanan pasangannya dan tidak memberi dampak negatif kepada pasangannya ataupun orang lain.

“...saya mikir juga, yang pertama bagaimana calon istri saya tidak suka perokok...” (AB, 27 tahun, Lk)

“...masa cowok saya ngerokok, kamu berhenti aja? Saya gak suka, (...), ee mulai perlahan lahan saya juga berhenti..." (AG, 20 tahun, Lk)

Selain motif kesehatan, informan juga berhenti merokok karena motif non kesehatan. Motif non kesehatan tersebut diantaranya karena faktor finansial dan religi. Informan mulai menyadari bahwa pengeluaran untuk membeli rokok lebih besar dibandingkan pengeluaran untuk kebetutuhan seharihari khususnya makan. Hal tersebut yang menjadi dasar informan memutuskan untuk berhenti merokok. Adapun kutipan wawancara informan sebagai berikut.

\begin{abstract}
"Oh iya yang pertama faktor uang (...) ketika sudah beres kita baru berpikir oh iya rokok itu gini gini, saya menyadarinya itu sendiri karena rokok yang saya beli cukup diatas rata rata gitu, rata rata diatas anak muda gitu biasanya kan saya malioboro, essence kan itu diatas rata rata, (...) kondisi keuangan saya waktu itu menurun jadi perlahan lahan saya berhenti..." (AG, 20 tahun, Lk)
\end{abstract}

Informan juga menganggap bahwa faktor religi mempengaruhi untuk berhenti merokok karena rokok merupakan sesuatu yang haram sesuai dengan beberapa fatwa dari ulama.

\section{“...yang pertama itu kita harus menyadari sesungguhnya rokok itu tiada guna tidak ada manfaat (...) Tembakau itu haram..." (AB, 27 tahun, Lk)}

Sebelum informan benar-benar berhenti merokok dengan alasan yang telah disebutkan di atas, terdapat keinginan awal yang menginisiasi informan untuk berhenti merokok, walaupun upaya berhenti merokok yang telah mereka lakukan tidak berhasil. Keinginan tersebut meliputi keinginan dari dalam diri untuk lebih baik, pengaruh saran dari dokter saat memeriksakan kesehatan dan pengaruh dari pacar yang melarang merokok.
"Awalnya sempet ada karena dilarang pacar dulu. Cuma ga bertahan lama berhenti nya. Terus sampe akhirnya saya hamil ya udah ga mau lagi gituuu” (DS, 21 tahun, Pr)

\section{Dukungan Sosial}

Informan mengungkapkan bahwa selama berhenti merokok, mereka mendapatkan dukungan secara emosional, instrumental dan adanya informasi baik secara langsung maupun secara tidak langsung. Dukungan emosional dan interaksi negatif biasanya didapatkan secara langsung dari pasangan, keluarga dan teman, sedangkan dukungan instrumental dan informasi didapatkan secara tidak langsung. Dukungan emosional yang didapatkan berupa nasihat, apresiasi untuk tidak merokok, semangat, dan teguran.
“...teman teman yang lebih meyakinkan saya dan membantu saya berhenti saya itu men- gapresiasi saya termaksud teman teman yang baru saya temui sekarang "' (AG, 20 ta- hun, Lk)

Dukungan instrumental dan informasi yang didapatkan secara tidak langsung, yaitu adanya peraturan larangan merokok di wilayah kampus. Namun, hal tersebut tidak memberikan konstribusi yang besar terhadap perokok untuk berhenti merokok. Larangan merokok hanya terimplementasi di dalam ruangan kelas, selebihnya mereka dapat merokok di luar ruangan seperti taman kampus.

\footnotetext{
“...aturan kampus juga kalau di luar kalau di area taman kampus, itu gak ada larangan merokok kalau di dalam kelas memang kami yah gak pernah merokok karena itu area terlarang tapi kalau di depan ditaman taman kampus sering merokok sebelum diskusi sebelum masuk kelas juga, masuk kelas ngerokok dan keluar kelas ngerokok..." (AB, 27 tahun, Lk)
}

Informan mendapatkan dukungan informasi mengenai dampak negatif merokok diberbagai fasilitas kesehatan, melalui media poster dan flyer. Selain itu, informasi didapatkan dari media sosial seperti Youtube dan Facebook.

\footnotetext{
“...ketika di puskesmas di rumah sakit ada tulisan dibagian ini ada bahayanya apa zatnya..." (AB, 27 tahun, Lk)
} 
Dukungan sosial juga didapatkan oleh informan yang belum berhasil berhenti merokok. Dukungan sosial dijadikan sebagai reminder atau pengingat bagi mereka untuk menguatkan diri berhenti dari aktivitas merokok. Akan tetapi, dukungan tersebut tidak memberikan pengaruh yang signifikan. Hal ini dikarenakan efek yang ditimbulkan rokok belum begitu parah dirasakan oleh informan, sehingga dukungan tersebut tidak terlalu berdampak pada informan. Hal yang penting adalah usaha dan kekuatan dari dalam diri mereka sendiri.

\section{Mekanisme Coping}

Infoman menerapkan beberapa strategi dalam berhenti merokok, baik pemilihan metode berhenti merokok secara langsung atau bertahap, strategi mengurangi withdrawal syndrome dan memperkuat kekuatan dalam diri. Berbagai usaha yang dilakukan untuk mengatasi stressor adalah dengan cara menghindari lingkungan perokok, mengalihkan perhatian, dan memberi sugesti pada diri sendiri agar tidak merokok. Tujuan informan melakukan kegiatan-kegiatan positif yaitu untuk menghabiskan atau memanfaatkan waktu sehingga dapat terhindar dari keinginan merokok. Kegiatan positif yang dimaksud oleh informan seperti ikut organisasi, membaca buku, mengedit video, bermain musik atau game, bersepeda, berdiskusi dengan teman menggulakan aplikasi chat dan tidur.

“...saya tidur aja akhirnya dari pada mikirin mulu, ya udah tiduran saja” (DS, 21 tahun, $\operatorname{Pr)}$

"Saya sengaja memang menyibukkan diri dengan kegiatan organisasi...” (AB, 27 tahun, Lk)

"Selain itu yang ketiga saya kalau tidak ada kegiatan organisasi, saya di perpus, baca apapun saya kerjakan id perpus agar saya tidak pulang cepat..." (AB, 27 tahun, Lk)

Upaya lain yang dilakukan adalah dengan cara mengalihkan perhatian. Mengalihkan perhatian yang dimaksud adalah usaha yang dilakukan informan untuk mengurangi rasa asam yang ada di mulut ketika telah berhenti merokok. Bentuk pengalihan perhatiannya dengan meminum air es atau kopi, mengkon- sumsi cemilan atau permen, dan menggigit es batu.
“...biasanya kalau lagi asem kayak begitu kadang ee minum air es jadi gigit-gigitin ba- tu es terus atau ee ngemil ngemil kayak apa ajalah kayak mungkin kacang, apa ciki, apa apa pokoknya dicemilin cemilin..." (DS, 21 tahun, Pr)

Godaan paling sulit dihadapi informan adalah lingkungan sekitar mereka yang dikelilingi oleh banyak perokok. Hal itu dapat mempengaruhi keinginan informan untuk merokok kembali. Strategi yang digunakan informan untuk mengatasi hal tersebut dengan menghindari lingkungan perokok. Bentuk menghindari lingkungan perokok yang dilakukan seperti pergi ke ruangan ber AC, pergi ke perpustakaan, menghindari teman yang merokok, berhubungan dengan orang yang tidak merokok, dan mematahkan rokok teman.

“saya ngajak mereka itu ke tempat yang
AC...” (DS, 21 tahun, Pr)
“...bikin aturan pribadi atau aturan dikantor
kalau anda ketua atau punya wewenang atau
jabatan dikantor, jangan atau dilarang
merokok dikantor itu akan mempengaruhi
anda...” (AB, 27 tahun, Lk)

Hal terakhir yang dilakukan informan sebagai bentuk mekanisme coping ialah menyugesti diri sendiri untuk menghindari godaan merokok dengan mengubah mindset dan mengingat risiko yang akan terjadi kedepannya.

\begin{abstract}
“...mindsetnya dirubah, gak asem gak asem gak asem, karena kan kalau kata orang sih katanya semua berawal dari pikiran, jadi gak asem gak asem jadi ya udah akhirnya lupa sendiri rasa asem itu" (DS, 21 tahun, Pr)
\end{abstract}

\section{PEMBAHASAN}

Penelitian ini menemukan faktor sosial seperti pergaulan dengan teman sebaya dan faktor dari dalam diri berupa rasa penasaran dan coba-coba. Biasanya seseorang akan belajar kepada temannya terkait cara menghisap dan mengeluarkan asap rokok. Rasa ingin tahu tentang rokok merupakan prediktor yang mempengaruhi penggunaan rokok dan merupakan tahap awal terbentuknya perilaku 
merokok di kalangan remaja. ${ }^{14,15}$. Remaja mendapat pengaruh dari lingkungan sosial terutama di sekolah terhadap status perokok, semakin banyak bergaul dengan teman perokok maka remaja yang merokok akan lebih mudah terpengaruh untuk merokok. ${ }^{16,17}$ Salah satu cara yang dilakukan dengan mengatakan seseorang yang merokok bukan seorang lelaki (banci). Anak lelaki akan mudah mengadaptasi simbol-simbol sosial yang tumbuh di masyarakat berkaitan dengan maskulinitas dan perilaku merokok sebagai bentuk kedewasaan dari remaja tersebut. ${ }^{18,19}$ Hal tersebut menempatkan derajat kemaskulinan mereka lebih rendah dibandingkan seseorang yang merokok, sehingga mereka akan merasa tertantang untuk mencoba rokok.

Perokok akan terus merokok karena faktor lingkungan sosial perokok, stres dan faktor finansial. Perokok mengkonsumsi rokok untuk menghilangkan stres karena stressor sosial dan ekonomi serta adanya permasalahan pribadi atau keluarga dan perasaan negatif serta mendapatkan ketenangan dan perasaan yang lebih baik. ${ }^{20,21}$ Alasan lain karena perokok memiliki penghasilan sendiri untuk membeli rokok. Faktor finansial member berpengaruh terhadap aspek penggunaan rokok seperti inisiasi merokok, merokok saat ini, tingkat merokok, dan ketergantungan terhadap rokok. ${ }^{22-27}$

Penelitian ini menemukan bahwa perokok berhenti merokok karena mengalami pengalaman buruk berupa sakit akibat orang tua merokok yang dialami sewaktu masa anak-anak. Pengalaman yang dialami tersebut dijadikan sebagai bahan pembelajaran agar anak yang dikandungnya tidak mengalami sakit yang sama seperti yang dirasakan. Wanita yang memiliki tingkat motivasi yang lebih tinggi untuk meningkatkan kesehatan mereka sendiri dan bayi mereka lebih cenderung untuk berhenti merokok pada masa kehamilan. ${ }^{28}$ Salah satu alasan mantan perokok dengan riwayat penyakit pernapasan akibat rokok adalah untuk mengurangi perkembangan risiko masalah kesehatan yang dialami. ${ }^{29}$

Alasan lainnya perokok berhenti merokok karena ingin mengubah perilakunya menjadi lebih sehat dan tidak mau memberikan dampak negatif pada lingkungan, faktor religi dan finansial. Beberapa penelitian juga mengungkapkan bahwa seorang perokok biasanya berhenti merokok karena faktor kesehatan agar terasa lebih bugar ketika melakukan aktifitas. ${ }^{30,31}$ Perokok yang memiliki pasangan yang tidak menyukai merokok memberikan hubungan postif terhadap upaya berhenti merokok pada pasangannya. $^{32}$ Selain itu, faktor religi merupakan salah satu alasan seseorang berhenti merokok. Hal ini dikarenakan adanya larangan-larangan yang difatwakan oleh ulama dan berdasarkan dalil-dalil yang menyerukan bahwa rokok adalah benda haram. ${ }^{33}$ Faktor religiusitas dan spiritualitas memiliki hubungan postif terhadap perilaku merokok dan religiusitas sebagai faktor protektif terhadap perilaku merokok. ${ }^{34}$ Tekanan karena faktor finansial memberikan pengaruh dalam proses berhenti merokok karena secara tidak langsung mengurangi pengeluaran untuk kebutuhan lainnya. ${ }^{35-39}$

Berhenti merokok secara langsung atau bertahap merupakan pilihan strategi yang biasa diterapkan oleh setiap perokok dalam berhenti merokok. Strategi berhenti sangat erat kaitannya dengan metode yang digunakan oleh perokok. Kedua strategi tersebut akan sukses apabila seseorang memiliki kekuatan dalam diri untuk berhenti merokok. Kekuatan tersebut terdiri atas niat, motivasi, kepercayaan diri, komitmen, pengambilan keputusan dan manajemen niat merupakan hal yang paling mendasar yang harus dimiliki seseorang untuk berhenti merokok. Perilaku berhenti merokok sangat bergantung pada niat, tekad dan motivasi yang tinggi dari dalam seseorang sehingga kemungkinan untuk berhasil berhenti merokok ikut meningkat. ${ }^{31,40,41}$ Salah satu bentuk komitmen yang dilakukan seorang perokok untuk berhenti merokok adalah berani menolak dan katakan 'tidak' kepada teman yang mengajak untuk merokok. Walaupun ada beberapa orang yang tidak berani mengatakan 'tidak' karena menghindari image sombong yang dikatakan temannya. Bentuk penolakan yang dapat dilakukan untuk menghindari image tersebut yaitu dengan cara menolak dengan cara berbohong seperti mengatakan hari ini tidak merokok karena sakit atau kurang sehat. Keinginan dan komitmen dalam melakukan perubahan merupakan hal yang terpenting da- 
lam keberhasilan penghentian perilaku merokok. $^{42}$

Dalam menghentikan kebiasaan perilaku merokok, seseorang harus berani mengambil risiko yang diambil berdasarkan keputusan yang akan dilakukan untuk menghentikan kebiasaan merokoknya. Pengambilan keputusan tersebut kaitannya dengan strategi coping yang akan dilakukan, kapan harus berhenti merokok dan berbagai keputusan lainnya yang didasari kepercayaan diri. Pemilihan waktu yang tepat sangat berpengaruh dalam penghentian merokok. Salah satu yang dapat dilakukan adalah berhenti merokok pada saat momen bulan Ramadhan. Saat Ramadhan, tidak ada yang merokok pada siang hari. Hal ini yang membuat para tenaga kesehatan menyarankan kepada masyarakat agar memanfaatkan bulan Ramadhan sebagai langkah awal upaya berhenti merokok. ${ }^{43-46}$

Hambatan berhenti merokok bersumber dari dalam dan maupun luar diri setiap individu. Hambatan dari dalam luar berupa tidak ada larangan merokok di beberapa area kampus seperti taman kampus, adanya tawaran atau ajakan merokok dari teman, perkataan negatif dari teman, ketemu dan bergaul dengan perokok, banyak ruang tak ber-air conditioner (AC), kerabat. Lingkungan kerja dan teman bergaul perokok merupakan faktor yang mempersulit atau menghambat keberhasilan dalam berhenti merokok karena selalu disuguhi dan ditawari, adanya ledekan dari teman, dan mencium bau asap rokok. ${ }^{47,48}$ Hambatan dari dalam diri berupa godaan yang begitu kuat untuk merokok karena adanya masalah yang sedang dihadapi, melihat orang yang merokok, dan sugesti dari dalam diri untuk merokok. Pada fase awal berhenti merokok, efek candu rokok belum sepenuhnya hilang sehingga keinginan merokok akan selalu timbul pada saat kondisi-kondisi tertentu. Kecanduan, melihat teman yang merokok, ketegangan, penambahan berat badan, kebosanan, kegagalan dalam pemecahan masalah merupakan hambatan yang sering dihadapi dalam berhenti merokok. ${ }^{31,49-51}$ Menurut Childs dan de $\mathrm{Wit}^{52}$, stres memberikan pengaruh yang signifikan terhadap keinginan merokok, tapi tidak meningkatkan kebiasaan merokok. Namun, seseorang yang dapat mengatasi stres dan situasi yang menekan selama berhenti merokok kemungkinan dapat meningkat keberhasilan dalam upaya berhenti merokok di kalangan perokok yang termotivasi untuk berhenti merokok. ${ }^{53}$

Dalam penelitian ini, dukungan sosial hanya sebagai moderator dalam membantu mereka untuk berhenti merokok karena mengkontrol diri sendiri untuk tidak merokok merupakan hal yang terpenting, bukan nasihat dari orang lain untuk berhenti merokok. Perokok mendapatkan dukungan dari teman, keluarga dan pasangannya. Selain itu, perokok mendapat dukungan informasi dan instrumental berupa larangan merokok. Dukungan dari keluarga, teman, anti kontak sosial lainnya merupakan faktor protektif yang membantu seseorang dalam mengurangi tekanan emosional, mencegah timbulnya penyakit, untuk mengurangi keparahan penyakit, atau untuk meningkatkan pemulihan dari penyakit serta masalah-masalah kesehatan yang dialami. $^{54,55}$ Seorang perokok yang mendapatkan tekanan dan dukungan lebih banyak dari pasangan dan keluarganya akan cenderung melakukan usaha berhenti merokok, berhenti selama 3 bulan dan berkontribusi untuk menjaga perokok mencoba untuk menghentikan kebiasaan. ${ }^{56-58}$ Seseorang yang aktif mencari informasi kaitannya dengan kesehatan dapat mempengaruhi perilaku kesehatan khususnya informasi mengenai berhenti rokok, karena dapat meningkatkan niat untuk menjalani perawatan berhenti merokok. ${ }^{59,60}$ Dukungan sosial sangat penting selama proses inisiasi berhenti merokok karena memiliki pengaruh dalam peningkatan strategi coping yang mengarah pada aspek positif dalam penentuan strategi coping yang dilakukan sehingga coping dapat dilakukan dengan baik dan berdampak pada pengurangan risiko mengalami stress. ${ }^{56,61}$

Coping diartikan sebagai upaya khusus yang berorientasi pada perilaku dan psikologis untuk mengelola, mengurangi atau meminimalisir peristiwa-peristiwa yang dapat menimbulkan stres dan berdampak pada kesehatan mental dan fisik. ${ }^{62,63}$ Setiap individu memiliki variasi masa-masa sulit yang dihadapi yaitu pada sebulan pertama berhenti merokok, 3 bulan pertama hingga 6 bulan pertama berhenti merokok. ${ }^{47}$ Penelitian ini menemukan bahwa salah satu strategi yang 
bisa dilakukan untuk meminimalisir stres akibat tidak merokok yaitu menyugesti pikiran dengan mengubah mindset atau cara merubah pola pikir seseorang terhadap rokok. Sugesti diri sendiri sangat jarang dilakukan oleh para perokok. Sugesti biasanya digunakan oleh para psikiater melalui metode hipnosis. Menurut Covino dan Bottari ${ }^{64}$ hipnotis merupakan metode persepsi, emosi, dan atau perilaku seseorang melalui sugesti, perhatian terfokus, dan hubungan terapeutik. Menurut McDougall $^{64}$ sugesti menyebabkan orang bereaksi tanpa refleksi kritis dan menerima proposisi yang dikomunikasikan dengan keyakinan tanpa adanya alasan yang cukup logis.

Strategi coping lain yang dilakukan adalah dengan cara mengalihkan perhatian rokok dengan mengganti rokok dengan makanan dan minuman seperti minum air es, mengemil dan memakan permen. Hal tersebut dilakukan untuk menggantikan sesuatu yang hilang dari mulutnya dan menghilangkan rasa asam. Beberapa penelitian mengungkapkan bahwa perokok dapat mengalihkan perhatian terhadap rokok dengan mengganti rokok dengan hal lain seperti mengunyah permen, ngemil dan minum air putih. ${ }^{31,47,65}$ Temuan dalam penelitian, salah satu cara yang bisa dilakukan untuk mengganti rokok adalah dengan menggigit es batu. Tujuan menggigit es batu untuk memanipulasi asap rokok dengan uap yang menyerupai asap kabut yang dihasilkan dari proses penguapan es di dalam mulut sehingga seseorang akan merasa asap tersebut seperti asap rokok. Hal ini relevan dengan yang diungkapkan Wills and Shiffman ${ }^{66}$ bahwa coping memiliki peran penting dalam mencegah tingginya dorongan untuk merokok melalui pengurangan pengaruh negatif misalnya dengan menghindari situasi risiko tinggi atau hal-hal yang dapat memicu merokok. Hal tersebut dapat meningkatkan efikasi diri dan meningkatkan kemampuan seseorang untuk mengatasi dorongan untuk merokok.

Menghindari lingkungan perokok merupakan strategi yang paling efektif untuk berhenti merokok. Menghindari lingkungan perokok yang dimaksud adalah menghindari teman yang merokok dan mengupayakan ketempat-tempat yang memungkinkan seseorang untuk tidak merokok misalnya ru- angan berAC atau perpustakaan. Lingkungan perokok merupakan godaan terbesar yang dihadapi informan dalam proses berhenti merokok. Menurut Donovan dan Jessor sebanyak $70 \%$ perokok karena pengaruh teman yang merokok. Upaya yang harus dilakukan adalah dengan menghindari pergaulan tersebut agar dapat mengontrol keinginan untuk merokok. ${ }^{31,67}$

Cara lain yang dapat dilakukan adalah dengan melakukan hal-hal positif yang untuk mengurangi perasaan jenuh akibat tidak merokok. Biasanya perokok akan merasa sepi dan jenuh ketika tidak merokok karena rokok telah dianggap sebagai teman untuk menghilangkan rasa bosan dan jenuh. Oleh karena itu, untuk memanfaatkan waktu tersebut, perlu melakukan hal-hal yang dapat menyibukan diri melalui aktifitas yang hubungannya dengan hobi dan aktifitas positif lainnya seperti main musik, main video game, ikut organisasi, chatting, tidur, membaca bu$\mathrm{ku}$, mendengarkan musik, bersepeda. Melakukan aktifitas positif merupakan salah cara efektif dalam mengontrol konsumsi rokok karena dapat meminimalkan dan mengalihkan perhatian waktu kosong yang memungkinkan seseorang untuk merokok. ${ }^{28,65}$

\section{KESIMPULAN}

Perokok berhenti merokok karena motif kesehatan (ingin lebih sehat, tidak memberi dampak negatif terhadap orang lain dan lingkungan, pengalaman buruk yang dialami) dan motif non kesehatan (merokok adalah haram dan pengeluaran membeli rokok lebih banyak dari kebutuhan untuk makan). Dukungan sosial sebagai moderator dalam berhenti merokok. Coping sebagai pengendali dalam berhenti merokok

\section{SARAN}

Perlu penguatan regulasi mengenai rokok dan memperluas kawasan bebas asap rokok. Implementasi kebijakannya pun perlu diterapkan secara optimal.

\section{UCAPAN TERIMA KASIH}

Terima kasih kepada program studi magister kesehatan masyarakat, fakultas kedokteran, kesehatan masyarakat, dan keperawatan, 
Universitas Gadjah Mada dan seluruh informan yang terlibat dalam penelitian.

\section{DAFTAR REFERENSI}

1. Eriksen M, Mackay J, Schlunger N, Gomeshtapeh FI, Drop J. The Tobacco Atlas. Fifth. Vol. 80, The Quarterly Review of Biology. Georgia: American Cancer Society; 2015.

2. Kemenkes RI. Perilaku Merokok Masyarakat Indonesia Berdasarkan Riskesdas 2007 dan 2013. Infodatin Pusat Data Informasi Kementerian Kesehatan RI. 2015. p. 1-12.

3. Dinas Kesehatan DIY. Laporan Rekapitulasi Cakupan PHBS. Dinas Kesehatan DIY: Yogyakarta; 2017.

4. Syafiie RM, Frieda N, Kahija Y La. Stop Smoking!: Studi Kualitatif Terhadap Pengalaman Mantan Pecandu Rokok dalam Menghentikan Kebiasaannya. 2009;1-21.

5. World Health Organization. Global Adult Tobacco Survey: Indonesia Report 2011. 2012. 1-182 p.

6. RSRespira. Kunjungan konseling berhenti merokok. Rumah Sakit Paru Respira Bantul ; DIY; 2016.

7. Brose LS, West R, Michie S, McEwen A. Changes in success rates of smoking cessation treatment associated with of a national evidence-based training programme. Prev Med (Baltim). 2014;69:1-4.

8. Prochaska JO, DiClemente CC. Stages and processes of self-change of smoking: Toward an integrative model of change. J Consult Clin Psychol. 1983;51(3):390-5.

9. Glanz K, Rimer BK, Viswanath K. Health Behavior and Health Education: Theory, Research and Practice. San Fransisco: Jossey-Bass; 2008.

10. Breslau N, Peterson EL. Smoking cessation in young adults: Age at initiation of cigarette smoking and other suspected influences. Am J Public Health. 1996;86(2):214-20.

11. Wang IJ, Gjengedal E, Larsen T. "Passed and cleared" - former tobacco smokers' experience in quitting smoking. Glob Health Promot.
2014;21(2):57-65.

12. Smith AL, Carter SM, Chapman S, Dunlop SM, Freeman B. Why do smokers try to quit without medication or counselling? A qualitative study with ex-smokers. BMJ Open. 2015;5(4):e007301.

13. Donev D, Pavlekovic G, ZaletelKragelj L. Social Networks and Social Support in Health Promotion Programmes. 2008; (January 2015).

14. Guo Q, Unger J, Palmer P, Chou C-P, Johnson A. The Role of Cognitive Attributions for Smoking in Subsequent Smoking Progression and Regression among Adolescents in China. Addict Behav. 2013;13(2):8396.

15. Portnoy DB, Wu CC, Tworek C, Chen J, Borek N. Youth curiosity about cigarettes, smokeless tobacco, and cigars: Prevalence and associations with advertising. Am J Prev Med. 2014;47(2 SUPPL. 1):S76-86.

16. Hitchman SC, Fong GT, Zanna MP, Thrasher JF, Laux FL. The relation between number of smoking friends, and quit intentions, attempts, and success: Findings from the international tobacco control (ITC) four country survey. Psychol Addict Behav. 2014;28(4):1144-52.

17. Bellatorre A, Choi K, Bernat D. The Influence of the Social Environment on Youth Smoking Status. Prev Med. 2015;

18. Courtenay WH. Constructions of masculinity and their influence on men's well-being: A theory of gender and health. Soc Sci Med. 2000;50(10):1385-401.

19. $\mathrm{Ng} \mathrm{N}$, Weinehall $\mathrm{L}$, Öhman A. "If I don't smoke, I'm not a real man" Indonesian teenage boys' views about smoking. Health Educ Res. 2007;22(6):794-804.

20. Tsourtos G, Ward PR, Muller R. Smoking and stress: The double-edged sword of living in a disadvantaged area. Australas Med J. 2008;1(1).

21. Shuaib F, Foushee HR, Ehiri J, Bagchi S, Baumann A, Kohler C. Smoking, 
sociodemographic determinants, and stress in the Alabama Black Belt. J Rural Heal. 2010;27(1):50-9.

22. Advani PS, Reitzel LR, Nguyen NT, Fisher FD, Savoy EJ, Cuevas AG, et al. Financial Strain and Cancer Risk Behaviors among African Americans. Cancer Epidemiol Biomarkers Prev. 2014;23:967-75.

23. Hernandez DC, Reesor L, Reitzel LR, Businelle MS, Wetter DW, Kendzor DE. Smoking, Financial Strain, and Food Insecurity. Heal Behav Policy Rev. 2017;4 (2):182-188 (7).

24. Siahpush M, Borland R, Scollo M. Smoking and financial stress. Tob Control. 2003; 12(1):60-6.

25. McKenna CS, Law C, Pearce A. Financial Strain, Parental Smoking, and the Great Recession: An Analysis of the UK Millennium Cohort Study. Nicotine Tob Res. 2016;(April):ntw269.

26. Perelman J, Alves J, Pfoertner T-K, Moor I, Federico B, Kuipers MAG, et al. The association between personal income and smoking among adolescents: a study in six European cities. Addiction. 2017;

27. Widome R, Joseph AM, Hammett P, Van Ryn M, Nelson DB, Nyman JA, et al. Associations between smoking behaviors and financial stress among low-income smokers. Prev Med Reports. 2015;2:911-5.

28. Leung LWS, Davies GA. Smoking Cessation Strategies in Pregnancy. J Obstet Gynaecol Canada. 2015;37(9):791-7.

29. Jones A. Diagnosis on Smoking Cessation. Br J Nurs. 2017;26(14).

30. Turner L, Mermelstein R, Flay B. Individual and contextual influences on adolescent smoking. Ann N Y Acad Sci. 2004;1021:175-97.

31. Sensussiana T. Studi Fenomenologi; Pengalaman Perubahan Perilaku Berhenti Merokok Tahap Action dan Manitenance Berdasarkan Transtheortical Theory pada Remaja di SMAN 1 Cawas. Tesisi. Yogyakarta: Universitas Gadjah Mada; 2016.
32. West R, McEwen A, Bolling K, Owen L. Smoking cessation and smoking patterns in the general population: a 1year follow-up. Addiction. 2001;96(6):891-902.

33. Surat Keputusan Pimpinan Pusat Muhammadiyah. Fatwa Majelis Tarjih dan Tajdid Pimpinan Pusat Muhammadiyah

No.6/SM/MTT/III/2010 Tentang Hukun Merokok. 2010;(6):1-8.

34. Koenig HG. Spirituality and Health Research; Methods, Measurement, Statistics, and Resources. West Conshohocken, PA: Templeton Press; 2011.

35. Busch SH, Jofre-Bonet M, Falba TA, Sindelar JL. Burning a hole in the budget: Tobacco spending and its crowd-out of other goods. Appl Health Econ Health Policy. 2004;3(4):263-72.

36. Wang H, Sindelar JL, Busch SH. The impact of tobacco expenditure on household consumption patterns in rural China. Soc Sci Med. 2006;62(6):1414-26.

37. Guillaumier A, Bonevski B, Paul C. "Cigarettes are priority": A qualitative study of how Australian socioeconomically disadvantaged smokers respond to rising cigarette prices. Health Educ Res. 2014;30(4):599-608.

38. Yao T, Huang J, Sung H-Y, Ong MK, Mao Z, Jiang Y, et al. Determinants of smoking-induced deprivation in China Tingting. Tob Control. 2015;24 (4):iv35-iv39.

39. Kendzor DE, Businelle MS, Waters AF, Frank SG, Hébert ET. Financial strain indirectly influences smoking cessation through withdrawal symptom severity. Drug Alcohol Depend. 2018;183(June 2017):55-61.

40. Fawzani N, Triratnawati A. Terapi Berhenti Merokok: Studi Kasus Tiga Perokok Berat. J Kesehat. 2005;9 (I); 15-.

41. Torre G La. Smoking Prevention and Cessation. Rome, Italy: Spinger; 2013.

42. Kahler CW, LaChance HR, Strong DR, Ramsey SE, Monti PM, Brown RA. 
The commitment to quitting smoking scale: Initial validation in a smoking cessation trial for heavy social drinkers. Addict Behav. 2007;32(10):2420-4.

43. Chandola T, Head J, Bartley M. Sociodemographic predictors of quitting smoking: How important are household factors? Addiction. 2004;99(6):770-7.

44. Ghouri N, Atcha M, Sheikh A. Influence of Islam on smoking among Muslims. $\mathrm{Br} \quad$ Med J. 2006;332(7536):291-4.

45. Mahroof R, Syed R, El-Sharkawy A, Hasan T, Ahmed S, Hussain F. Ramadan health guide. 2007;30.

46. Aveyard P, Begh R, Sheikh A, Amos A. Promoting smoking cessation through smoking reduction during Ramadan. Addiction. 2011;106(8):1379-80.

47. Asropi. Efikasi Diri Mantan Perokok Dalam Mempertahankan Perilaku Tidak Merokok (Studi Kualitatif Mantan Perokok di Kabupaten Bengkulu Utara). Tesis. Yogyakarta: Universitas Gadjah Mada; 2016.

48. Siriwong S. Exploring Quitting Smoking Behavior Among Royal Thai Navy Personnel With the Transtheoretical Model. Procedia - Soc Behav Sci. 2015;191:1062-8.

49. Rimer BK, Orleans CT, Keintz MK, Cristinzio S, Fleisher L. The older smoker. Status, challenges and opportunities for intervention. Chest. 1990;97(3):547-53.

50. Kerr SM, Watson H, Tolson D, Lough M, Brown M. Other Developing evidence-based smoking cessation training/education initiatives in partnership with older people and health professionals. Glasgow, Scotland: Caledonian Nursing \& Midwifery Research Centre; 2004.

51. Schofield I, Tolson D. An exploration of the smoking-related health beliefs of older people with chronic obstructive pulmonary disease. J Clin Nurs. 2007;16:1726-35.

52. Childs E, de Wit H. Effects of acute psychosocial stress on cigarette craving and smoking. Nicotine Tob Res. 2010;12(4):449-53.

53. Skov-Ettrup LS, Egan KK, Dalum P, Tolstrup JS. Stress-related expectations about smoking cessation and future quit attempts and abstinence - a prospective study in daily smokers who wish to quit. Prev Med Reports. 2017;6:187-90.

54. Porritt D. Social support in crisis: Quantity or quality? Soc Sci Med Part A Med Psychol Med. 1979;13(C):71521.

55. Rausa BA. Social Support. Encycl Aging Public Heal. 2008;751-4.

56. Mermelstein R, Cohen S. Social support and smoking cessation and manteinance. J Consult Clin Psychol. 1986;(4):447-53.

57. Burns RJ, Rothman AJ, Fu SS, Lindgren B, Joseph AM. The Relation between Social Support and Smoking Cessation: Revisiting an Established Measure to Improve Prediction. 2014;47(3):369-75.

58. De Jesus MCP, Da Silva MH, Cordeiro SM, Kortchmar E, De Barros Zampier VS, Merighi MAB. Understanding unsuccessful attempts to quit smoking: A social phenomenology approach. Rev da Esc Enferm. 2016;50(1):71-8.

59. Van Der Rijt GAJ, Westerik H. Social and cognitive factors contributing to the intention to undergo a smoking cessation treatment. Addict Behav. 2004;29(1):191-8.

60. Bigsby E, Hovick SR. Understanding Associations between Information Seeking and Scanning and Health Risk Behaviors: An Early Test of the Structural Influence Model. Health Commun. 2017;33(3):315-25.

61. Niven N. Psikologi Kesehatan Keperawatan Pengantar untuk Perawat dan Profesional Kesehatan Lain. Jakarta: EGC; 2002.

62. Taylor SE, Stanton AL. Coping Resources, Coping Processes, and Mental Health. Annu Rev Clin Psychol. 2007;3(1):377-401.

63. Jannone L, O'Connell KA. Coping strategies used by adolescents during 
smoking cessation. J Sch Nurs. 2007;23(3):177-84.

64. Covino N a, Bottari M. Hypnosis, behavioral theory, and smoking cessation. J Dent Educ. 2001;65(4):340-7.

65. Sugito. Stop Merokok. Jakarta: Penebar Swadaya; 2009.

66. Brodbeck J, Bachmann MS, Znoj H. Distinct coping strategies differentially predict urge levels and lapses in a smoking cessation attempt. Addict Behav. 2013;38(6):2224-9.

67. Apriyani T, Evi AH. Mengapa Late Chilhood Merokok? J Hum vol2. 2011; 